\title{
NEW LOCALITY OF LEPIDIUM CARTILAGINEUM IN THE HORTOBÁGY REGION (EAST HUNGARY)
}

\author{
András Schmotzer \\ Bükk National Park Directorate, Sánc u. 6, H-3304 Eger, Hungary; \\ E-mail: schmotzera@bnpi.hu
}

\begin{abstract}
A new locality of the halophyte Lepidium cartilagineum (J. C. Mayer) Thell. (Brassicaceae) was recorded at the eastern margin of the Hortobágy region, at Nagyhegyes. Despite the fact that the species is not rare in saline steppes in Hungary, it occurs exclusively on solonchak soils. The soil of the one previously documented location at Hortobágy region is not typical solonetz, with transitional solonchak characteristics. The locality found at 'Sirály-rét' (Elep, Nagyhegyes) is in a typical alkaline grassland, where the species grows in Puccinellietum limosae and transitional Camphorosmetum annuae communities. This contribution also includes 14 phytocoenological relevés taken at the locality and a comparison of the two, so far documented locations in the region. The author takes the position that this occurrence is to be regarded as native, mostly based on the habitat specifications (such as developed berm formations), vegetation structure and species composition. The continuity of the grassland patch is also proved by available historical maps and aerial photographs.
\end{abstract}

Keywords: Brassicaceae, distribution, flora mapping, alkalic vegetation, habitat preference

\section{INTRODUCTION}

Halophytic and sub-halophytic habitats are among the most characteristic and hence unique vegetation types of the Pannonian Basin (Fekete and Varga 2006, Molnár 2008, Fekete et al. 2011). Generations of naturalists and pedologists have studied the saline landscapes in the Pannonian Basin, which presently cover nearly 400000 hectares in Hungary (Molnár and Borhidi 2003, Tóth and Szendrei 2006). The soil - plant relationship is extraordinarily significant and based on the microrelief conditions clear vegetation units (alliances and associations) can be described (Bodrogközy 1965, Tóth 2011, Borhidi et al. 2012). Recently, the species composition of alkalic grasslands has also been studied on a larger 
geographical scale in a South-East European context (Eliáš et al. 2013, Stevanović et al. 2016). The distribution of typical halophytes is mainly determined by the soil type. In accordance with the main alkalic soil types (solonetz and solonchak) the vegetation and the distribution of the diagnostic species of the vegetation units show significant differentiation. Rapaics (1930) was the first who described this phenomenon - calling it the 'Újszász-Szeged dividing line' -, presenting distribution maps for 11 alkalic plants. Recent floristic surveys have also proved the existence of this border line, interpreted mostly as a transition zone. The present expansion of maritime and continental salt-tolerant plants is also noteworthy in Central Europe (e.g. Limonium gmelini (Hohla et al. 2015, Kocián 2016), Colchlearia danica (Fekete et al. 2018), Spergularia species (Schmidt et al. 2018, Kúr et al. 2018), Plantago coronopus (Schmidt et al. 2016)). This process is man-derived through transport and the development of new constructed landscape elements such as highways.

The case of Lepidium cartilagineum (J. C. Mayer) Thell. is slightly different. It is a characteristic species of sand based solonchak alkalic vegetation and a surprisingly new location was found in a natural habitat in the Hortobágy (Novák and Matus 2000). In this paper the author presents the second occurrence of this species in the region, found at Nagyhegyes (East Hungary).

Lepidium cartilagineum belongs to the Lepidium genus, Lepidieae DC tribe of the Brassicaceae family (Al-Shehbaz et al. 2006). It is regarded as a Eurasian halophyte species ranging from Western Siberia to the Pannonian Basin (Meusel 1965). As far as we know, the westernmost occurrence is at Neusiedler See (or Lake Fertő) in Burgenland, Austria (Csapody 1965, Fischer and Fally 2006). The species now only occurs on the Austrian side of the lake (Király and Takács 2020). The eastern range of the species is still data deficient, although several current sources have proved its occurrences in Ukraine (Ilyinska 2014), Turkey (Bona 2012, 2014), Russia (German 2008, 2012, Dorofeyev 2018), Pakistan (Khan and Qaiser 2006) and even in China (Kefu et al. 2002). The taxonomic separation of the western populations of its area is not evident, the taxon here is described as "L. crassifolium "by Waldstein and Kitaibel (1799) from Fejér County ("Crescit in locis salsis siccis sterilissimis Comitatus Albensis solo instar lapidis duro in quo praeter novam Camphorosmas speciem fere nullum aliud vegetabile 
crescit."). This name is treated now mostly as a synonym of $L$. cartilagineum or mentioned only as a subspecies rank in $L$. cartilagineum subsp. crassifolium (Waldst. \& Kit.) Thell. (Marhold in EURO+MED 2011). Some authors regard the species as a Pannonic (sub)endemic species (Soó 1964, Novák and Matus 2000).

The distribution of the species in the Carpathian Basin is wellknown (Bartha et al. 2015). It is known in all microregions on lowlands where solonchak alkalic soils are present. In the Eupannonicum flora region it occurs in the Kiskunság, on the Soltiand Csepel Plain and on the Lower Tisza Plain. The Mezőföld landscape unit belongs to the Colocense flora region, where the species also occurs. Occurrences are also documented from the Crisicum flora region, especially from its western margin (e.g. Tápió region, Hatvan Plain and Jászság). East of the Tisza river, where the solonetz soil becomes predominant in alkalic steppes, it had no confirmed occurrence before a single population in Hortobágy was discovered by Novák and Matus (2000). One additional report is known close to Debrecen (Lesku and Molnár 2007), but this stand of $L$. cartilagineum was not yet confirmed according to the last years' inventories (Lesku pers. comm.). Nowadays L. cartilagineum occurs in 124 flora-mapping grids according to the online version of the Atlas Flora Hungariae (http://floraatlasz.uni-sopron.hu/, accessed 20.10.2020).

The objective of this study is to present the newly discovered locality of $L$. cartilagineum in the Hortobágy region, with special attention on its habitat preference.

\section{MATERIALS AND METHODS}

For describing the habitat conditions of the newly discovered locality, 14 phytosociological relevés were taken, using the CentralEuropean Phytosociological School method (Braun-Blanquet 1932). I sampled only such vegetation patches where $L$. cartilagineum covers at least $15 \%$ of the relevé size (which was 1 square meter). I presented percentage of cover data for the vascular plant species. Nomenclature of flowering plants is according to Király (2009). Nomenclature of plant syntaxa follows Borhidi et al. (2012). Geocoordinates of the locality and the relevés were determined using a Spectra MobileMapper GPS device and converted to WGS-84 projection. The distribution map (Figure 1) was prepared in the 
ArcGIS 10.1 software environment. The grid numbering of the location follows the codes of the Central European Flora-mapping Project (Niklfeld 1971, Király 2003). The voucher specimen is deposited in the Herbarium Carpato-Pannonicum collection of the Hungarian Natural History Museum, Budapest (ID number: HNHMTRA 00127570).

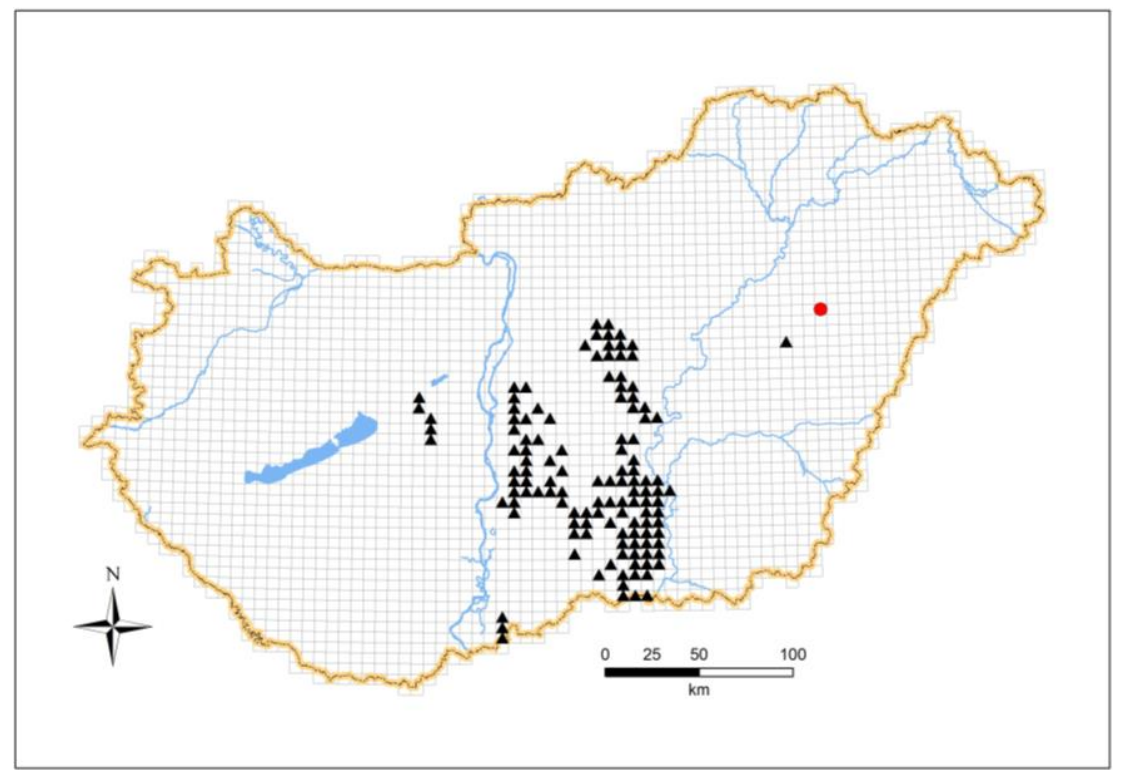

Figure 1. Present distribution of Lepidium cartilagineum in Hungary (red dot is the new locality presented in this paper).

\section{RESULTS AND DISCUSSION}

Discovery of the new locality of Lepidium cartilagineum in the Hortobágy region

On 21st May 2018 in the framework of the Land Use / Cover Area frame statistical Survey (LUCAS, Sutcliffe et al. 2019) I visited a location in Nagyhegyes municipality (reference of the LUCAS point is 51702776). A strong population of L. cartilagineum in a late flowering state was detected on a saline steppe at the LUCAS sampling point and in its surroundings. The site was revisited on $26^{\text {th }}$ of May 2018 in order to (i) estimate the population size (incl. individual number and cover of the patches with L. cartilagineum) and (ii) record phytosociological relevés with the species studied. 
The location is situated in 'Sirály-rét' at Nagyhegyes municipality in the border strip of two landscape units, the Hortobágy and the Hajdúság (centroid coordinates: N47,511870 and E21,314040 ; altitude: 89 metres a.s.l.; CEU grid code: 8493/4). The broader toponym of the place is Elep (or Elep-puszta). The landscape pattern is rather mosaic here, both natural (e.g. alkalic grasslands, wetlands, scattered forests) and anthropogenic habitats occur (e.g. arable fields, abandoned livestock barns and farmsteads, forest plantations, fishponds and linear objects such as canals and asphalt roads). The line of the Keleti-föcsatorna ('Main Eastern Canal') is a remarkable landscape element here, lying approx. 600 metres eastwards from the locality. Nagyhegyes municipality (Hajdú-Bihar County) is situated approx. 3.5 kilometres north-east from the site. I found an estimated 5500 individuals occurring in a rather restricted, circa one-hectare large area.

\section{Habitat characterisation of the locality}

The Hortobágy (Middle Tisza region on the Great Hungarian Plain) is the largest coherent occurrence of an alkali habitat type in Europe, covering an area of ca. $2300 \mathrm{~km}^{2}$ (Sümegi et al. 2013). Its geographical features, paleoecology, land-use history and diverse flora and vegetation and ethnobotany have been studied by several authors (e.g. Rapaics 1916, Soó 1934, Bodrogközy 1965, SzujkóLacza et al. 1982, Molnár 2009, 2013, Novák 2010, Sümegi et al. 2013). The continuous cover grasslands ('steppes') disintegrates at the eastern edge of the Hortobágy towards to Hajdúság and a mosaic landscape feature becomes predominant.

The habitat of L. cartilagineum is situated in an alkalic grassland, traditionally managed by sheep grazing. The extent of the grassland has fluctuated according to the available historical maps and aerial photographs (Figure 2). Nowadays it covers approx. 200 hectares. The grassland patch can be divided into two parts, differing in landuse history, microtopology and, consequently, vegetation. The western part of the grassland was formerly used for rice production, and the former irrigation dykes are still recognisable from terrain and aerial photos. In the communist era, in the 1950's, rice cultivation was forcibly developed especially in the Hortobágy region, where numerous irrigation channels and fishponds were created (Penyige 1962, Hajdú 2006). At that time, the farmsteads around Elep functioned as labour camps. The surface here is very 
flat, and is poor in microforms due to former rice cultivation, which was abandoned in the 1980's. The most frequent plant associations here are the Achillea alkalic steppes (Achilleo setaceae-Festucetum pseudovinae Soó (1933) 1947 corr. Borhidi 1996) and degraded loessy grasslands (Cynodonti-Poëtum angustifoliae Rapaics ex Soó 1957). In gentle depressions alkali wet meadows (mainly Agrostio stoloniferae-Alopecuretum pratensis Soó 1933 association) also occur. The eastern part of the grassland forms a narrow border zone where typical salt berm formations ('padkás szik', according to Tóth et al. 2015) are significant. L. cartilagineum occurs only in this part of the grassland, where typical alkalic vegetation zonation is developed. Suitable habitats with salt berms ('szik padka') and blind-szik ('vakszik') for eu-halopytes cover maximum one hectare.
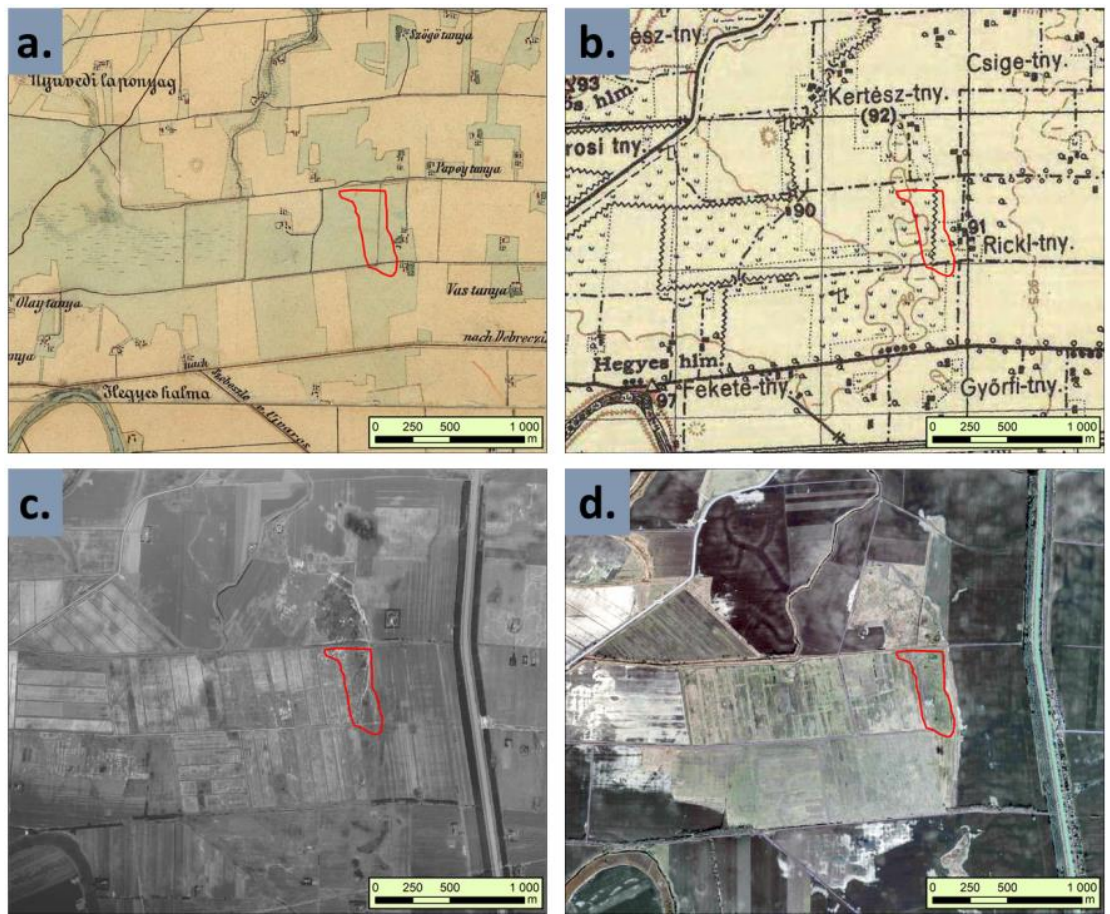

Figure 2. Location of Lepidium cartilagineum at Nagyhegyes (Elep) in the past 150 years on historical maps [a) Second military survey of the Habsburg Empire (1860); b) military survey of Hungary (1941), and on satellite images: c) national aerial photograph (1965) and d) Bing Satellite Image (accessed 20.10.2020)]. Red polygons represent the present habitat of the species. 
L. cartilagineum occupies the gentle berm slopes and the flat depression areas where the high salt content is exposed on the surface. In mid-May the berms are dominantly covered by the late blossoming L. cartilagineum (Figure 3). The species is characteristic in natural berms, but also occasionally occurs on wheel tracks.

The species composition of the locality belongs to the Puccinellion limosae Soó 1933 alliance, resp. Puccinellietum limosae Magyar ex Soó 1933 plant association, which is typical on solonetz soils (Borhidi et al. 2012). The analytical table of the habitat is shown in Table 1. The cover of the herb layer varies between 47 and $82 \%$ (avr.: 60.4\%; \pm 9.42). The height of the herb layer is between 2 and 20 centimetres; the cryptogamic layer was not developed at the period of sampling. Altogether 12 vascular species occur in the 14 relevés, the species number per plot is between 2 and $8(4.64 \pm 1.74)$. Due to extreme abiotic conditions the species poorness of alkalic habitats is typical and is regarded as a natural phenomenon.

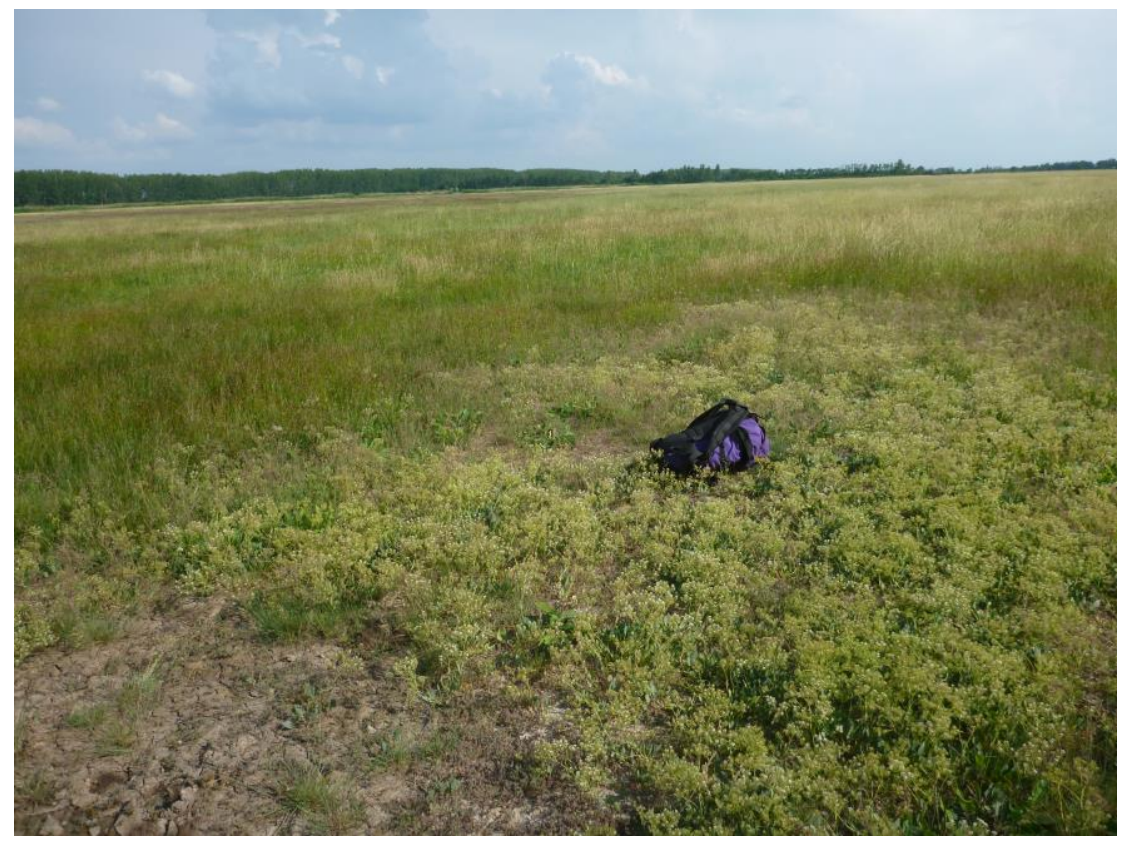

Figure 3. Habitat of Lepidium cartilagineum at Nagyhegyes (21 ${ }^{\text {st }}$ May 2018) (photo of A. Schmotzer). 
A higher species number is only presumed when anthropogenic disturbance is characteristic (esp. in the case of the Hordeetum hystricis Wendelbg. 1943 community). All species occurring in the relevés are typical in alkalic habitats. The dominant species beside L. cartilagineum (frequency: V) - are Puccinellia limosa (V), Camphorosma annua (IV) and Limonium gmelini (III) (Figure 4). These four dominant species form the majority of the plant cover of the habitat (min: 93.8\%; max: 100\%; avr. 99.3\%; \pm 1.6 ). Beside these species only Artemisia santonicum can reach 1\% cover, in only one relevé (nr. 3). The typical fescue grass of alkalic steppes, Festuca pseudovina is missing from the relevés, but is dominant on the loessy ridges. Bromus hordeaceus and Polygonum aviculare agg. have a weedy character, but both species are typical in alkalic habitats.

Table 1. Floristic composition of the patches with Lepidium cartilagineum.

\begin{tabular}{|c|c|c|c|c|c|c|c|c|c|c|c|c|c|c|c|}
\hline Nr. of relevé & 1 & 2 & 3 & 4 & 5 & 6 & 7 & 8 & 9 & 10 & 11 & 12 & 13 & 14 & Fr. \\
\hline Coverage (\%) & 47 & 51 & 53 & 64 & 52 & 71 & 56 & 81 & 63 & 53 & 65 & 55 & 68 & 65 & \\
\hline $\begin{array}{l}\text { Species } \\
\text { number }\end{array}$ & 6 & 4 & 4 & 6 & 5 & 5 & 8 & 7 & 3 & 4 & 2 & 4 & 5 & 2 & \\
\hline $\begin{array}{l}\text { Lepidium } \\
\text { cartilagineum }\end{array}$ & 35 & 45 & 45 & 25 & 22 & 40 & 20 & 30 & 30 & 15 & 50 & 30 & 30 & 30 & $\begin{array}{c}\mathrm{V} \\
(14)\end{array}$ \\
\hline $\begin{array}{l}\text { Puccinellia } \\
\text { limosa }\end{array}$ & 8 & 3 & 4 & 6 & 20 & 15 & 25 & 45 & 30 & 30 & 15 & 12 & 25 & 35 & $\begin{array}{c}\mathrm{V} \\
(14) \\
\end{array}$ \\
\hline $\begin{array}{l}\text { Camphorosma } \\
\text { аппиа }\end{array}$ & 2 & 0.3 & 0.5 & 12 & 8 & 15 & 3 & 0.3 & - & 0.1 & - & 10 & 5 & - & $\begin{array}{l}\text { IV } \\
\text { (11) } \\
\end{array}$ \\
\hline $\begin{array}{l}\text { Limonium } \\
\text { gmelini }\end{array}$ & 1 & 3 & 3 & 20 & 2 & 1 & 5 & 6 & 3 & 8 & - & 3 & 8 & - & $\begin{array}{l}\text { III } \\
\text { (12) }\end{array}$ \\
\hline $\begin{array}{l}\text { Artemisia } \\
\text { santonicum }\end{array}$ & 0.5 & - & - & 0.5 & - & - & 3 & - & - & - & - & - & - & - & $\begin{array}{c}\text { I } \\
(3)\end{array}$ \\
\hline $\begin{array}{l}\text { Juncus } \\
\text { gerardii }\end{array}$ & - & - & - & 0.1 & - & 0.1 & 0.5 & - & - & - & - & - & - & - & $\begin{array}{c}\text { I } \\
(3)\end{array}$ \\
\hline $\begin{array}{l}\text { Aster } \\
\text { tripolium }\end{array}$ & - & - & - & - & - & - & - & 0.1 & - & - & - & - & 0.5 & - & $\begin{array}{c}\mathrm{I} \\
(2) \\
\end{array}$ \\
\hline $\begin{array}{l}\text { Spergularia } \mathrm{cf} \\
\text { salina }\end{array}$ & - & - & - & - & 0.3 & - & - & 0.5 & - & - & - & - & - & - & $\begin{array}{c}\text { I } \\
(2)\end{array}$ \\
\hline
\end{tabular}

Accompanying, accidental species with coverage percentage (\%) and number of the releve (in brackets): Bromus hordeaceus 0.1 (7), Cerastium dubium 0.1 (1), Polygonum aviculare agg. 0.1 (8), Trifolium angulatum 0.1 (7).

Relevés recorded by: András Schmotzer, Date: 26.05.2018., Location: Hungary, Hajdú-Bihar County, Nagyhegyes - toponym: 'Sirály-rét' (Elep). Position (centroid): $47.5121^{\circ} \mathrm{N}$ and $21.3136^{\circ}$ E. Altitude: 89 m. Exposition: -. Declination: flat. Plot size: $1 \mathrm{~m}^{2}$.

\section{Comparison of the presently known localities of Lepidium cartilagineum in the Hortobágy region}

The occurrence of the species in the Hortobágy region is unexpected. Novák and Matus (2000) found the first population in the region, at Ágota-puszta (Nádudvar). The location is situated in 
the southern part of the Hortobágy. They gave a precise description of the locality, including phytosociological relevés and pedological data. They presented 14 relevés, but $L$. cartilagineum occurred only in 7 samples. A comparison of the two known localities of $L$. cartilagineum in the Hortobágy region is summarized in Table 2.

At both sites L. cartilagineum occurs in a natural habitat (salt berm formations, mostly in Puccinellia swards), but in the vicinity secondary habitats also occur (abandoned arable land at Ágotapuszta or former rice fields at Nagyhegyes). The extent of both suitable habitats is rather small, although in Ágota-puszta the alkalic vegetation mosaic is relatively larger, in relation to the landscape level. The size of the population at Nagyhegyes is much larger (36-times) than in Ágota-puszta, exceeding 5000 individuals. The species pool of the habitat shows a slight difference between the locations. In Ágota-puszta, Festuca pseudovina and typical alkalic forbs (e.g. Artemisia santonicum, Podospermum canum) have a larger cover and frequency value than at Nagyhegyes. Most other features compared show minor differences between the localities (e.g. species number, vegetation cover).

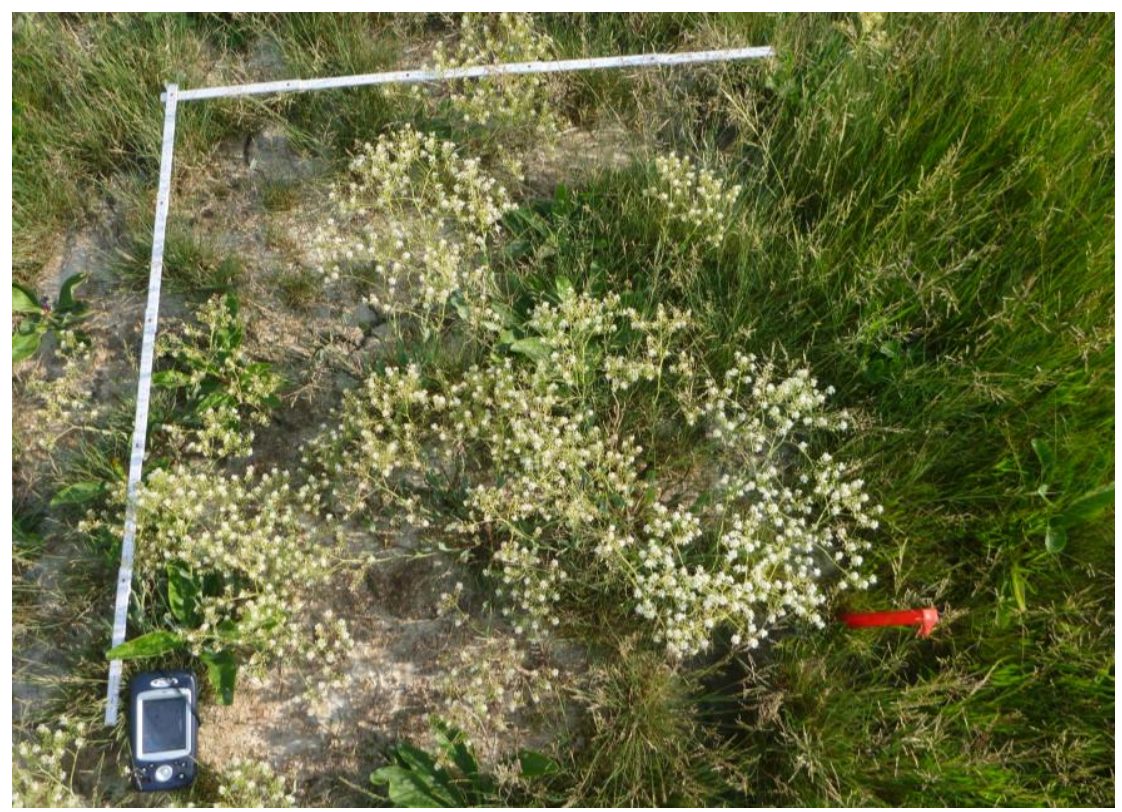

Figure 4. Quadrat photo of Puccinellia sward with dense cover of L. cartilagineum (photo of A. Schmotzer). 
Table 2. Comparison by selected features of the two known localities of Lepidium cartilagineum in the Hortobágy region.

\begin{tabular}{|c|c|c|c|c|}
\hline \multicolumn{2}{|c|}{ Feature } & $\begin{array}{l}\text { Location: Ágota- } \\
\text { puszta (Novák } \\
\text { and Matus 2000) }\end{array}$ & $\begin{array}{c}\text { Location: } \\
\text { Sirály-rét, Elep }\end{array}$ & Comments \\
\hline \multicolumn{2}{|c|}{$\begin{array}{l}\text { Extent of the } \\
\text { grassland }\end{array}$} & $\begin{array}{l}\text { over } 500 \\
\text { hectares }^{1 *}\end{array}$ & $\begin{array}{c}\text { approx. } 120 \\
\text { hectares }\end{array}$ & $\begin{array}{l}1 * \text { the locality } \\
\text { is part of the } \\
\text { grassland } \\
\text { core area of } \\
\text { Hortobágy }\end{array}$ \\
\hline \multicolumn{2}{|c|}{$\begin{array}{l}\text { Cover of patches with } \\
\text { L. cartilagineum }\end{array}$} & $437 \mathrm{~m}^{2}$ & $980 \mathrm{~m}^{2}$ & - \\
\hline \multicolumn{2}{|c|}{ Population number } & $\begin{array}{c}\text { approx. } 150 \\
\text { individuals } 2 *\end{array}$ & $\begin{array}{c}\text { approx. } 5500 \\
\text { individuals }\end{array}$ & $\begin{array}{c}2 * \text { incl. sterile } \\
\text { plants }\end{array}$ \\
\hline \multicolumn{2}{|c|}{ Vegetation type } & $\begin{array}{c}\text { alkalic steppe } \\
\text { with remarkable } \\
\text { salt berm } \\
\text { formations }\end{array}$ & $\begin{array}{c}\text { alkalic steppe } \\
\text { with remarkable } \\
\text { salt berm } \\
\text { formations } \\
\end{array}$ & $\mathrm{r}-\mathrm{mon}$ \\
\hline \multicolumn{2}{|c|}{$\begin{array}{l}\text { 'Top-3' covering } \\
\text { forbs beside } L \text {. } \\
\text { cartilagineum }\end{array}$} & $\begin{array}{l}\text { Puccinellia limosa } \\
\text { / Camphorosma } \\
\text { annua / Limonium } \\
\text { gmelini }\end{array}$ & $\begin{array}{c}\text { Puccinellia } \\
\text { limosa } \\
\text { /Artermisia } \\
\text { santonicum / } \\
\text { Festuca } \\
\text { pseudovina }\end{array}$ & - \\
\hline \multirow{2}{*}{ Cover } & $\begin{array}{l}\text { minimal } \\
\text { /average } \\
\text { /maximal } \\
\end{array}$ & $\begin{array}{c}50 / 60-90 / \\
100 \% 3^{3 *}\end{array}$ & 46 / 60 / 81\% & $3 *$ estimation \\
\hline & $\begin{array}{l}\operatorname{mean} \pm \\
\mathrm{SD}\end{array}$ & $79.071 \pm 11.507$ & $60.286 \pm 9.417$ & $\begin{array}{l}\text { t-test, } \mathrm{N}=14, \mathrm{P} \\
=<0.001 \\
\text { (significant) }\end{array}$ \\
\hline \multirow{2}{*}{$\begin{array}{l}\text { Species } \\
\text { number }\end{array}$} & $\begin{array}{l}\text { minimal } \\
- \\
\text { maximal } \\
\text { and total }\end{array}$ & $3-7,9$ & $2-8,12$ & - \\
\hline & $\begin{array}{l}\operatorname{mean} \pm \\
\mathrm{SD}\end{array}$ & $4.79 \pm 1.72$ & $4.64 \pm 1.74$ & $\begin{array}{c}\text { t-test, } N=14, P \\
=0,828 \text { (not } \\
\text { significant) }\end{array}$ \\
\hline
\end{tabular}




\section{CONCLUSIONS}

The main issue concerning the nativeness of L. cartilagineum populations in the Hortobágy region is still uncertain. The distance of the two known occurrences is 22 kilometres, so they are regarded as separate populations. Compared with other expanding halophytes, L. cartilagineum in the Hortobágy region shows a strong affinity to natural habitats, mostly to Puccinellia swards with developed microforms of the surface. This association forms a vegetation zone with the adjacent alkalic pioneer stands of Camphorosmaetum annuae Rapaics ex Soó 1933 and the wet Plantagini tenuiflorae-Pholiuretum pannonici Wendelbg. 1933 communities. Their transition belts can move depending on the rainfall for the current year (Zalatnai and Körmöczi 2004, Lukács and Radócz 2012). The separation of Pannonian alkaligrass meadows (Puccinellion limosae Soó 1933) is based on the main soil types according to the traditional classification (Borhidi et al. 2012). The Puccinellia swards on solonchak soils are treated under the Puccinellenion peisonis (Wendelbg. 1943 corr. Soó 1947) Borhidi 2003) suballiance, represented by the stands at Lake Fertő and on the Danube-Tisza interfluve. One of the main characteristic species of this group is L. cartilagineum, forming a typical alkalic association called Lepidio crassifolii-Puccinellietum limosae Soó (1947) 1957. The corresponding suballiance of this group on solonetz soil is Puccinellenion limosae (Varga \& V. Sipos ex Borhidi 2003), which is widespread in the Crisicum flora region. Nevertheless, it must be added that apart from L. cartilagineum no differential species is known in relation to the two abovementioned suballiances. Bodrogközy $(1966,1980)$ characterised a Puccinellietum sward from Fehér-tó, Orosháza (southern Tisza valley) as Lepidio-Puccinellietum limosae crisicum without the presence of $L$. cartilagineum. He indicated that Lepidium perfoliatum behaves as a vicariant species on solonchak soil at this locality. In the Hortobágy region and in alkalic places in Crisicum, $L$. perfoliatum is a rather common species, sometimes also occurring in ruderal non-halophytic places. But neither in the relevés of Matus and Novák (2000) nor at Nagyhegyes has this species been shown to play an important role in the species composition of the habitat. The native status of the species at Nagyhegyes is also confirmed by pedological data. The alkalization process in the 
Hortobágy is much older, dating back to the Late Pleistocene, than it was stated in several papers (Sümegi et al. 2013). At Nagyhegyes, in the Hajdúság landscape unit, light-coloured paleosoil (alkalic soil) was detected (Szöör et al. 1992), which also indicates the primary origin of the alkalic grasslands there. The construction of the 'Eastern Main Canal' between 1951 and 1956 could also have caused a change in soil and vegetation conditions, including rapid alkalization (Nagy 2012), but the historical maps and aerial photo sets proved a continuous presence of the alkalic grassland here. No other evidence is available concerning the possible impact of this canal on the present state of the studied grassland (Figure 2). Novák and Matus (2000) also described some theories supporting the adventive origin of the species in the Hortobágy region, e.g. adventive occurrence far from the Pannonian Basin at Mannheim (Germany) existed or the proximity of a main road between Szolnok and Debrecen. It should be noted that the abovementioned historical salt and post road is situated 500-800 metres southwards from the Nagyhegyes location. The deficiency of floristic data for the eastern margin of the Hortobágy is also remarkable, making it difficult to formulate a conclusion concerning the origin of the species. It is also noteworthy that the so far known locations of L. cartilagineum grows on the landscape margins of the Hortobágy, some authors considered these stands belonging to Hajdúság landscape units (Endes 2019). At present there seem to be more factors - esp. site characteristic, naturalness, and spatial continuity of the grassland - that suggest that the occurrences of L. cartilagineum should be original. Although $L$. cartilagineum is neither a rare species in Hungary (not listed as a plant under nature protection) nor mentioned in the red list categorisation (Király 2007), the occurrences in the Hortobágy and Hajdúság regions should deserve special attention in the future.

Acknowledgements - The 2018 LUCAS grassland module was coordinated by the Institute for Agroecology and Biodiversity (IFAB, Mannheim, Germany) and funded by the European Commission through Eurostat (ESTAT/E/2017/010). The author would like to thank the reviewers, Gábor Matus (Debrecen) and Balázs Lesku (Debrecen) for their valuable comments and further literature sources. I am indebted also to Gergely Király (Sopron) for providing some literature. I am also grateful to Albert Vermes (Eger), who kindly improved the English of the revised version. 


\section{REFERENCES}

Al-Shehbaz, I.A., Beilstein, M.A., \& KellogG, E.A. (2006). Systematics and phylogeny of the Brassicaceae (Cruciferae): an overview. Plant Systematics and Evolution 259(2-4): 89-120. https://doi.org/10.1007/s00606-006-0415-z

Bartha, D., Király, G., Schmidt, D., Tiborcz, V., Barina, Z., CSiKY, J., JaKab, G., LeSKU, B., SCHMOTZER, A., VidÉKI, R., VojTKó, A. \& ZólYomi, Sz. (2015). Magyarország edényes növényfajainak elterjedési atlasza. (Distribution atlas of vascular plants of Hungary.) Nyugat-magyarországi Egyetem Kiadó / University of West Hungary Press, Sopron, 329 pp.

BодRоGкӧZY, Gy. (1965). Ecology of the halophylic vegetation of the Pannonicum II. Correlation between alkali ("szik") plant communities and genetic soil classification in the Northern Hortobágy. Acta Botanica Hungarica 11: 1-51.

BodroGKöZY, Gy. (1966). Ecology of the halophytic vegetation of the Pannonicum V. Results of the investigation of the "Fehértó" of Orosháza. Acta Botanica Hungarica 12: 9-26.

BodrogköZY, Gy. (1980). Szikes puszták és növénytakarójuk. (Natronpusstas und ihre Vegetation). A Békés Megyei Múzeumok Közleményei 6: 29-50.

Bona, M. (2012). Distribution of Lepidium taxa in Turkey. Bocconea 24: 221-225.

BonA, M. (2014). Taxonomic revision of Lepidium L. (Brassicaceae) from Turkey. Journal of Faculty of Pharmacy of Istanbul University 44(1): 31-62.

Borhidi, A., Kevey, B. \& Lendvai, G. (2012). Plant communities of Hungary. Akadémiai Kiadó, Budapest, 544 pp.

Braun-Blanquet, J. (1932). Plant sociology (Transl. Fuller, G.D \& Conrad, H.S.). McGraw-Hill, New York, 539 pp.

Csapody, I. (1965). Die Vegetation des Neusiedlersees und seiner Umgebung. Wissenschaftliche Arbeiten aus dem Burgenland 32: 42-57.

Dorofeyev, V.I. (2018). Genus Lepidium (Cruciferae) North-Eastern Euroasia. In: Budantzev (ed.): "Botany in the modern world". Proceedings of the XIV. Congress of the Russian Botanical Society. Makhachkala. vol. 1. pp. 36-39.

Eliáš, P., Sopotlieva, D., Dítě, D., Hájková, P., Apostolova, I., Senko, D., MelečKová, Z. \& HájEK, M. (2013). Vegetation diversity of salt-rich grasslands in Southeast Europe. Applied Vegetation Science 16(3): 521-537. https://doi.org/10.1111/avsc.12017

ENDES, M. (2019). Zsálya (Lepidium crassifolium) peres ügye. (Litigation of Lepidium crassifolium). Calandrella 21-22: 44-47.

Euro+Med (2011-). Euro+Med PlantBase - the information resource for EuroMediterranean plant diversity. Published on the Internet http://ww2.bgbm.org/EuroPlusMed/[accessed 10.10.2020].

FEKETE, G. \& VARGA, Z. (eds.) (2006). Magyarország tájainak növényzete és állatvilága. (Flora and fauna of the Hungarian landscapes). MTA Társadalomtudományi Központ, Budapest, 486 pp.

Fekete, G., Molnár, Zs, Magyari, E., Somodi, I. \& Varga, Z. (2011). Egyediség, szabályszerüség és deviáció a Pannon Régió vegetációjának példáján. (Individualities, regularities and deviations: example of the vegetation in the Pannonian Region). Botanikai közlemények 98(1-2): 29-59. 
Fekete, R., Mesterházy, A., Valkó, O. \& Molnár, V.A. (2018). A hitchhiker from the beach: the spread of the maritime halophyte Cochlearia danica along salted continental roads. Preslia 90: 23-37. https://doi.org/10.23855/preslia.2018.023

FisCHER, M.A. \& FALLY, J. (2006). Pflanzenführer Burgenland. Naturraum, Vegetationstypen und Flora des Burgenlandes. Kleiner Exkursionsführer zu botanisch interessanten Wanderzielen. Botanische Fachausdrücke. 759 häufige, charakteristische und besondere Pflanzenarten, 563 davon auf 694 Farbfotos: 2., vollständig überarbeitete u. erweiterte Aufl. Deutschkreutz: Eigenverlag Mag. Dr. Josef Fally, 384 pp.

German, D.A. (2008). A checklist and the system of Cruciferae of Altai. Komarovia 6(2): 80-88.

German, D.A. (2012). Typification of some names in the Cruciferae, mostly from north Asia. Turczaninowia 15(3): 9-16.

Hohla, M., Diewald, W. \& KirÁLY, B.G. (2015). Limonium gmelini - eine Steppenpflanze an österreichischen Autobahnen sowie weitere Neuigkeiten zur Flora Österreichs. Stapfia 103: 127-150.

HAJDÚ, Z. (2006). A szocialista természetátalakítás kérdései Magyarországon, 1948-1956. (Questions of socialist remaking of nature in Hungary between 1948-1956). In: Kiss, A., MezősI, G. \& SüMEGHY, Z. (eds.): Táj, környezet és társadalom: ünnepi tanulmányok Keveiné Bárány Ilona professzor asszony tiszteletére. SZTE Éghajlattani és Tájföldrajzi, Természetföldrajzi és Geoinformatikai Tanszék, Szeged, pp. 245-258.

ILYINSKA, P.A. (2014). Lepidium s. str. (Brassicaceae) in the flora of Ukraine. Biodiversity Research and Conservation 35(1): 25-29. https://doi.org/10.2478/biorc-2014-0016

KHAN, M.A. \& QAISER, M. (2006). Halophytes of Pakistan: characteristics, distribution and potential economic usages. In: KHAN, M.A., BöER, B., KuST, G.S. \& BARTH, H.J. (eds.): Sabkha Ecosystems. Tasks for Vegetation Science, vol. 42., Springer, Dordrecht. pp. 129-152. https://doi.org/10.1007/978-1-4020-5072-5_11

Kefu, Z., HaI, F. \& UnGaR, I.A. (2002). Survey of halophyte species in China. Plant Science 163(3): 491-498. https://doi.org/10.1016/S0168-9452(02)00160-7

KIRÁLY, G. (2003). A magyarországi flóratérképezés módszertani alapjai. Útmutató és magyarázat a hálótérképezési adatlapok használatához. (Methodik und Ziele der Florenkartierung in Ungarn). Flora Pannonica 1(1): 3-20.

KIRÁLY, G. (ed.) (2007). Vörös Lista. A magyarországi edényes flóra veszélyeztetett fajai. (Red list of the vascular flora of Hungary). Saját kiadás, Sopron, 73 pp.

KIRÁLY, G. (ed.) (2009). Új magyar füvészkönyv. Magyarország hajtásos növényei. Határozókulcsok. (New Hungarian Herbal. The vascular plants of Hungary). Aggteleki Nemzeti Park Igazgatóság, Jósvafő, 616 pp.

KIRÁLY, G. \& TAKÁCS, G. (2020). A magyar Fertő edényes flórája. (Vascular flora of the Lake Fertő in Hungary). Rence 3. Fertő-Hanság Nemzeti Park Igazgatóság, Sarród, $430 \mathrm{pp}$.

Kocián, P., Danihelka, J., Lengyel, A., Chrtek, J. Jun., Ducháček, M. \& KúR, P. (2016). Limonka Gmelinova (Limonium gmelinii) na dálnicích České republiky (Limonium gmelinii on highways in the Czech Republic). Acta Rerum Naturalium 19: 1-6. 
KÚR, P., PACHSCHWÖLL, C. \& ŠTECH, M. (2018). Notes on the distribution of Spergularia echinosperma and the newly recognized species $S$. kurkae in Austria. Neilreichia 9: 269-282. https://doi.org/10.5281/zenodo.1196424

LeSKu, B. \& Molnár, A. (2007). A Hortobágy növényritkaságai. (Plant rarities of Hortobágy). Daru füzetek. Hortobágyi Nemzeti Park Igazgatóság, Debrecen, $120 \mathrm{pp}$.

LUKÁCS, B.A. \& RADóCz, Sz. (2012). Vegetációátmenetek dinamikája szikes élőhelykomplexumokban, eltérő csapadékjárású években. (The effects of precipitation growth on vegetation transitions in alkaline habitat complexes). Természetvédelmi Közlemények 18: 326-337.

MEusel, H., JÄGER, E. \& WEINERT, E. (1965). Vergleichende Chorologie der zentraleuropäischen Flora. Vol 1. Gustav Fischer Verlag, Jena, $583+258$ pp.

MolnÁR, Zs. (2008). A Duna-Tisza köze és a Tiszántúl növényzete a 18-19. század fordulóján II.: szikesek, lösz- és homokvidékek, legelők, sáncok, szántók és parlagok. (Vegetation of the Duna - Tisza köze and Tiszántúl regions at the turn of the 18-19th centuries II.: alkali, sand and loess steppes, pastures, arable fields and old fields). Botanikai Közlemények 95(1-2): 39-63.

MoLNÁR, Zs. (2009). A Hortobágy hazánk egyik legősibb növényzetű tája. Válogatás az MTA Ökológiai és Botanikai Kutatóintézet Kutatási eredményeiből, ÖBKI Mühelyfüzetek, 2. Vácrátót, pp. 143-148.

MoLNÁR, Zs. (2013). Traditional vegetation knowledge of the Hortobágy salt steppe (Hungary): a neglected source of information for vegetation science and conservation. Phytocoenologia 43(3-4): 193-205.

http://dx.doi.org/10.1127/0340-269X/2013/0043-0561

MolnÁR, Zs. \& BoRHIDI, A. (2003). Hungarian alkali vegetation: Origins, landscape history, syntaxonomy, conservation. Phytocoenologia 33(2-3): 377-408. http://dx.doi.org/10.1127/0340-269x/2003/0033-0377

NAGY, S. (2012). A Keleti-főcsatorna múltja, jelene és jövője. (Past, present, and future of the Main Eastern Canal). Debreceni Szemle 20(1-2): 3-15.

Novák, T. \& Matus, G. (2000). Lepidium crassifolium W. et K. a Hortobágyon. Kitaibelia 5(1): 189-194.

NovÁK, T.J. (2010). A Hortobágy tájföldrajzi jellemzése. (Physio-geographical characteristics of Hortobágy). Acta Biologica Debrecina supplementum Oecologica Hungarica 24(1): 11-19.

NikLfEld, H. (1971). Bericht über die Kartierung der Flora Mitteleuropas. Taxon 20(4): 545-571.

Penyige, D. (1962). A rizstermesztés története Magyarországon. (Rice production in Hungary). In: Kállay, K. (ed.): A rizs és termesztése. Mezőgazdasági Kiadó, Budapest. pp. 16-34.

RAPAICS, R. (1916). A Hortobágy növényföldrajza. (Plant geography of the Hortobágy). Gazdasági Lapok 68(10):102-103.

RAPAICS, R. (1930). Az újszász-szegedi választóvonal. (The Újszász-Szeged dividing line). Föld és Ember 10: 48-54.

SchmidT, D., DítĚtová, Z., Horváth, A. \& SzŰCS, P. (2016). Coastal newcomer on motorways: the invasion of Plantago coronopus in Hungary. Studia botanica hungarica 47: 319-334. https://doi.org/10.17110/StudBot.2016.47.2.319 
Schmidt, D., Haszonits, G. \& KoRdA, M. (2018). Sótűrő budavirágfajok terjedése a Dunántúl útjain. (Spreading of native Spergularia species along roadsides of Transdanubia (NW Hungary)). Kitaibelia 23(2): 141-150. https://doi.org/10.17542/kit.23.141

Soó, R. (1934). A Hortobágy növénytakarója. (A szikespuszta növényszövetkezeteinek ökológiai és szociológiai jellemzése). Debreceni Szemle 8: 56-77.

Soó, R. (1964). A magyar flóra és vegetáció rendszertani-növényföldrajzi kézikönyve. (Synopsis systematico-geobotanica florae vegetationisque Hungariae). Akadémiai Kiadó, Budapest, vol. 3., 118 pp.

Stevanović, Z.D., Aćić, S., Luković, M., Zlatković, I., Vasin, J., Topisirović, G. \& Šilc, U. (2016). Classification of continental halophytic grassland vegetation of Southeastern Europe. Phytocoenologia 46(3): 317-331. https://doi.org/10.1127/phyto/2016/0076

Sutcliffe, L.M., SChraml, A., EISELT, B. \& OPPERMAnN, R. (2019). The LUCAS Grassland Module Pilot-qualitative monitoring of grassland in Europe. Palaearctic Grasslands 40: 27-31.

SÜMEgI, P., SZILÁGYI, G., Gulyás, S., JAKAB, G. \& MolnáR, A. (2013). The late quaternary paleoecology and environmental history of Hortobágy, a unique mosaic alkaline steppe. In: Morales Prieto, M.B. \& DiAz, J.T. (eds.): Steppe ecosystems: biological diversity, management and restoration, NOVA Publishers, New York, pp. 165193.

Szöőr, Gy, SüMEgI, E. \& BALÁzs, É. (1992). A Hajdúság területén feltárt felső pleisztocén fosszilis talajok szedimentológiai és geokémiai fácieselemzése. (Sedimentological and geochemical analysis of Upper Pleistocene paleosols of the Hajdúság region). In: Szöőr, Gy. (ed.): Fáciesanalitikai, paleobio-geokémiai és paleoökológiai kutatások. MTA Debreceni Akadémiai Bizottság, Debrecen, pp. 81-92.

Szujkó-Lacza, J., Fekete, G., Kováts, D., Szabó, L. \& Siroki, Z. (1982). The vascular plants of the Hortobágy National Park. In: SzujKó-LACZA, J. (ed.): The Flora of the Hortobagy National Park. Akadémiai Kiadó, Budapest, pp. 105-169.

Tóтн, T. (2011). Salt-affected soils and their native vegetation in Hungary. In: ÖZtürk, M., BöER, B., BARTh, H.J., ClÜSEner-Godt, M., Khan, M. \& BRECKLE, S.W. (eds.): Sabkha Ecosystems. Tasks for Vegetation Science, vol. 46.. Springer, Dordrecht, pp. 113-131. https://doi.org/10.1007/978-90-481-9673-9_13

Tóth, T. \& SzEnDREI, G. (2006). Types and distribution of salt affected soils in Hungary, and the characterisation of the processes of salt accumulation. Topographia Mineralogica Hungariae 9: 7-20.

Tóth, Cs., NovÁK, T. \& RAKonczAI, J. (2015). Hortobágy Puszta: Microtopography of alkali flats. In: Lóczy, D. (ed.): Landscapes and landforms of Hungary, Springer, Cham, pp. 237-246.

Waldstein, F.A. \& Kitaibel, P. (1799). Descriptiones et Icones Plantarum Rariorum Hungariae. Viennae, Vol 1: 4.

ZALATNAI, M. \& KöRMÖCZI, L. (2004). Fine-scale pattern of the boundary zones in alkaline grassland communities. Community Ecology 5(2): 235-246.

https://doi.org/10.1556/comec.5.2004.2.11

(submitted: 26.10.2020, accepted: 19.01.2021) 